v. $12, n .5$

Vitória-ES, Sep.-Oct. 2015

p. 97-117 ISSN 1808-2386 DOI: http://dx.doi.org/10.15728/bbr.2015.12.5.6

\title{
Brand Image and Awareness in the Third Sector and their Influence on the Intention to Donate
}

\author{
Arminda do Paço ${ }^{\dagger}$ \\ Beira Interior University \\ Luís Rodrigues ${ }^{\Omega}$ \\ Social Center Association of the Sagrado Coração de Maria \\ Ricardo Gouveia Rodrigues ${ }^{¥}$ \\ Beira Interior University
}

\begin{abstract}
The creation of a brand has been identified as a differentiating factor for non-governmental organizations (NGOs) when it comes to competing for private and public funding, as well as when trying to recruit volunteers. Thus, our purpose is to check whether the brand image that individuals associate with a specific NGO influences both fund raising and the recruitment of volunteers, using a questionnaire applied to a sample of 654 individuals. The results obtained show that usefulness and affect contribute to the intention to give financial aid to NGOs. When it comes to donating time, only efficiency is found to be a significant factor in the variability of that intention. In the case of the influence of brand awareness, we concluded that familiarity with the NGO contributes positively to the intention to donate.
\end{abstract}

Keywords: NGO. Branding. Brand image. Brand awareness. Third sector.

Received in 26/06/2014; revised in 07/08/2014; accepted in 11/08/2014; divulgued in 01/09/2015

*Author for correspondence:

${ }^{\dagger} \mathrm{PhD}$ in Management from the School of Social and Human Sciences of Beira Interior University

Institution: Assistant professor at Beira Interior University

Address: Estrada do Sineiro, Covilhã,

Portugal

E-mail: apaco@ubi.pt

Telephone: (+351) 275319639
${ }^{\Omega}$ Master's in Management from the School of Social and Human Sciences of Beira Interior University

Institution: Manager wtih the Social Center Association of the Sagrado Coração de Maria Address: Estrada do Sineiro, Covilhã, Portugal E-mail: luis.fa.rodrigues@gmail.com

Telephone: (+351) 275319639
${ }^{¥} \mathrm{PhD}$ in Management from the School of Social and Human Sciences of Beira Interior University

Institution: Assistant professor at

Beira Interior University.

Address: Estrada do Sineiro,

Covilhã, Portugal

E-mail: rgrodrigues@ubi.pt Telephone: (+351) 275319639

Note from the Editor: The article was accepted by Emerson Mainardes. 


\section{INTRODUCTION}

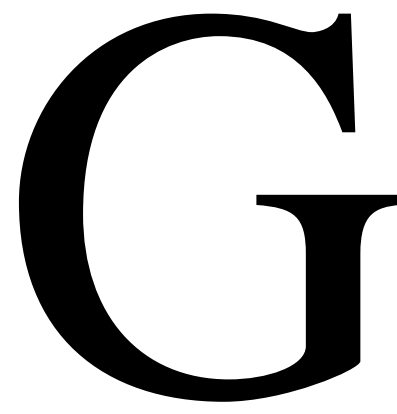

iven the strong growth in the number of nonprofit organizations, and the subsequent increase in competition for donations (MEWS; BOENIGK, 2013), the brand, through its system of identification (name, logo, color, etc.), has become an important factor for differentiation (MICHEL; RIEUNIER, 2012). Thus is quite relevant to understand which brand is most important in individuals' minds to improve their opinions and intentions to act in a cause related action (BAGHI; GABRIELLI, 2013).

Although there are as yet very few studies on nonprofit branding, some authors, such as Michel and Rieunier (2012), have studied this topic, especially the brand image, and have shown that the more favorable the brand image is, the greater may be the number of donations obtained. Despite its importance, the validity of research into nonprofit branding is considered somewhat weak due to problems related with "poor foundation" and lack of clarity regarding the exact meaning of the related brand constructs. In some cases, there are multiple definitions and scales for the same concept, and the confusion around the nomological network is very common (WYMER, 2013). However, Venable et al. (2005), noted that, despite the growing use made by NGOs of marketing techniques, there still remains a need for further research into such subjects as branding and brand personality. Nevertheless, in the opinion of Michel and Rieunier (2012), nonprofit brand personality has not been as widely explored as the studies presented by other authors illustrate (e.g., SARGEANT; HUDSON; WEST, 2008; SARGEANT; FORD; HUDSON, 2008; STINNETT; HARDY; WATERS, 2013).

It is recognized that some NGOs use brand personality as a differentiation tool. However, the existing studies are not very robust in the explanation of intentions to donate. Thus, Michel and Rieunier (2012) proposed expanding knowledge of the impact of brand image on donations, instead of focusing research on brand personality. For these authors, the concept of brand image can be useful to distinguish the roles of functional and symbolic associations of the brand without focus on specific aspects of image (e.g., personality characteristics or values).

The focus of this study is precisely that of branding, with a "brand" being understood as the set of perceptions formed about an organization, company or product, based on all communications, actions and interactions. It represents what people say, feel or think about a certain organization, company or product. In short, the brand is its reputation, identity and 
image in the eyes of stakeholders and the community. Thus, a strong brand can be a valuable asset for NGOs (DAW et al., 2010; BAGHI; GABRIELLI, 2013).

Beside the financial support to NGOs, there is also another type of donation that needs to be taken into account, one that is as important, if not more important than monetary donations - volunteering. For many organizations, volunteers represent a significant part of their workforce, with many of them depending solely on this type of work. The prestige and reputation of NGOs are therefore closely linked to the ease with which these organizations manage to obtain volunteers (WILSON; PIMM, 1996).

According to Guy and Patton (1988), NGOs should shape marketing techniques and adapt them to their own reality, centering their attention on satisfying precisely the needs of their main clients (users and donors).The research undertaken by these authors concluded that marketing for the third sector should first of all ensure that the public are aware of the needs of NGOs (i.e., their lack of resources) and that they are then approached for help in the form of donations. The problem of the low level of donations has been noticed in some countries, particularly in Portugal. The transfers from the private sector, which include private philanthropy, membership dues, corporate gifts, and other similar payments to nonprofit organizations, account for just 10\% of these entities' revenue (SALAMON et al., 2012).

The main aim of this research is to investigate how the brand image, measured by the dimensions proposed by Michel and Rieunier (2012) (usefulness, efficiency, affect and dynamism) and the familiarity that individuals associate with a certain NGO influences both fund raising and the recruitment of volunteers. Moreover, we intend to verify if there is some correlation between familiarity and typicality associated with the NGO.

The article has the following structure: we begin with a literature review that examines the applicability of branding to the nonprofit organizations, followed by the formulation of research hypotheses related to brand image, familiarity and typicality; next, we present the research methodology used, including a description of the sample, the variables included in the study and the data collection procedure; after this, the results are described, with a characterization of the sample and a discussion of the research hypotheses; finally, we present the main conclusions of the study.

\section{BRANDING IN NGOS}

The most prominent organizations operating within the third sector are NGOs, which group together all the institutions offering aid and social promotion that are fully independent 
of any form of organization by the State. They are nonprofit civil society associations with specific features that differentiate them from public organizations and other institutions (REES, 1998).

The growth in the number of NGOs has given rise to increased competition for the attention and contributions of donors, especially when it comes to winning new ones (Mews and Boenigk, 2013). In turn, the public sector does not have the necessary capacity, in terms of both human and financial resources, to intervene in the countless situations of shortage and need faced either by individuals or by the institutions which support them (FRUMKIN; KIM, 2001). Consequently, increased attention has been given to the management of marketing, and more particularly to the management of branding, as stressed by Mort, Weerawardena and Williamson (2007). Thus, brand managers tend to use management activities to generate some outcomes, as is the case of donations and volunteering. In turn, the donors and volunteers are influenced by the brand strength in its three dimensions: familiarity, attitude and remarkability (WYMER, 2013).

The brand strength refers to the degree to which a brand is well known, is perceived favorably and remarkably to a target (WYMER, 2013). Thus, creating and developing a strong brand is essential for the survival of most international NGOs (SMILLIE, 1995). Naddaff (2004) adds that branding has become an essential tool for the nonprofit sector and Chiagouris (2005) and Judd (2004) believe that having a strong brand image is even more important for NGOs than it is for commercial companies. For Webster (2002), the brand is the most valuable asset of a nonprofit organization.

Given the confusion over brand related constructs, it necessary to clarify some terms. A brand involves attributing an identity to a certain object, and the final form is the one that is known by the public (name, symbol, logo, etc.). In turn, brand image is the overall impression of the brand that is presented to the audience, which can be associated with some personality characteristics, "assuming" human traits (brand personality) (WYMER, 2013). In the particular case of nonprofit organizations, some scholars have identified brand personalities of well-known entities and have linked their brand personalities to fundraising support and intentions to donate (STINNETT; HARDY; WATERS, 2013).

Although the study of the brand image of NGOs has not yet aroused a great deal of attention on the part of researchers, the same thing no longer happens with the study of the brand personality of these organizations (MICHEL; RIEUNIER, 2012). In this particular area, 
Venable et al. (2005) firstly, and later Sargeant, Hudson and West (2008), used a model constructed with 42 sundry characteristics and the five dimensions of the brand assets proposed by Aaker (1991) to develop a more economical measurement of brand personality applied to the third sector. Using these three studies as their starting point, Michel and Rieunier (2012) performed first a qualitative and then a quantitative study aiming to develop a scale for measuring the brand image of NGOs. After the scale depuration process, four nonprofit brand image dimensions, which demonstrated sufficient reliability, emerged. Three items were used to assess Usefulness (useful, indispensable and civic minded); five items measured Efficiency (efficient, serious, well-managed, provides an excellent service to beneficiaries, and the charity uses its assets wisely); four items measured Affect (generous, warm, friendly, and engaging); and two items measured the last dimension, Dynamism (modern and innovative). These were also the dimensions we used to measure the NGOs' brand image.

Michel and Rieunier (2012) point out that despite the importance that is attached to the use of the brand as a tool of differentiation, so far only one study is known to have looked at the concept of brand image in the third sector. In their study, Bennett and Gabriel (2003) showed that a favorable brand image, consisting of five dimensions (compassion, dynamism, idealism, focus on beneficiaries and non-political image), resulted in more donations $\left(\mathrm{R}^{2}=0.69\right)$. However, according these authors the previous research is mainly based on concepts used in commercial rather than nonprofit branding. If the analogy with product branding is used, we can assume that brand image also influences individuals' attitudes and the donation behaviors in the context of nonprofits. In this case, donations include not only financial aid, but also the time spent volunteering in the organization (SAMU; WYMER, 2009). Note that usually time donations are more complex and the decision-making process is different, since it involves personal satisfaction and tends to be more emotional than a money donation decision (LIU; AAKER, 2008).

Following this line of reasoning, and considering that the donor's contribution to the organization may be made in the form of either time or money, we now formulate the first two hypotheses of this research regarding the importance of branding for NGOs:

$\mathrm{H}_{1}$ : The NGO's brand image influences the intention to give financial support.

$\mathrm{H}_{2}$ : The NGO's brand image influences the intention to donate time (volunteering). 
Einwiller (2001) defines brand awareness as the ability to remember a brand. He also states that the awareness and perception of a brand are dynamic attributes, linked to the perception and formation of attitudes. But the awareness of a brand is much more than its simple recognition, for it also implies a connection with certain associations in the consumer's memory (HOEFFLER; KELLER, 2002).

For Faircloth (2005), brand heritage is an important construct for NGOs to be able to understand and "manage" consumer behavior. The same author also points to brand awareness as an important factor in consumers' decision-making process.

Aaker (1996) states that brand awareness has various dimensions: brand knowledge/familiarity and brand recall/recognition. Wymer (2013) adds regarding brand familiarity that this concept refers to the amount of knowledge that the target has about the branded object. If the target is familiar with the organization, probably he or she is also aware of the NGO's brand image. Faircloth (2005) advocates the idea that widespread public awareness (knowledge) of NGOs results in an increase in volunteers and donations. Taking this idea as our starting point, and that familiarity is related with the time that is needed to process the information about a brand (Baker at al., 1986), we can expect that the greater people's familiarity with and recognition of an NGO are, the more likely the NGO will be to attract resources. The following hypotheses can therefore be formulated:

$\mathrm{H}_{3}$ : The greater the familiarity with the NGO is, the greater will be the intention to give financial aid.

$\mathrm{H}_{4}$ : The greater the familiarity with the $\mathrm{NGO}$ is, the greater will be the intention to donate time (volunteering).

Michel and Rieunier (2012) suggest that, just as brand image influences the intention to give time and money, the organization's typicality also has a significant impact on the intention to donate. Typicality is defined as the prototype of an organization that has the characteristics that NGOs are supposed to possess, i.e., one which comes close to the idea and/or association that individuals have of a certain NGO. In this context, it is useful to understand the concept of brand strength, defined by Wymer (2013) as the degree to which a brand is well known, is positively perceived and is notable or extraordinary (brand remarkability) to the target. However, for individuals to be able to consider an NGO typical, they have to be aware of its existence and be familiar with it. To check the veracity of this statement, the following hypothesis is formulated: 
$\mathrm{H}_{5}$ : The typicality noted in relation to the NGO is linked to familiarity.

\section{RESEARCH METHODOLOGY}

The sample for this study consisted of 654 Portuguese individuals, who agreed to take part in the survey. The sampling technique was not a random one, but sought to maximize the number of places where data could be collected, as well as their geographical dispersal, in order to make the sample as representative as possible. At the data collection points, the choice of respondents did not follow any particular selection criterion in order not to bias the choice. In order to try and fulfill the aim of this research, we decided to use a questionnaire administered in the form of a personal interview, a procedure that was previously tested with a group of 10 individuals. The questionnaire was designed to assess knowledge, typicality and familiarity, as well as the brand image and the intention to donate time and money.

In order to assess the respondents' knowledge of the brand, we used the measurement scale proposed by Keller (1993) and by Laurent et al. (1995). For measurement of the typicality and familiarity, we employed the scale developed by Faircloth (2005). The four dimensions of brand image were assessed with the scale developed by Michel and Rieunier (2012). The intention to collaborate with the NGO was measured with the scales of Faircloth (2005) and MacKenzie, Lutz and Belch (1986). These scales, which were already tested by other authors, were considered adequate for this study. The pre-test performed did not indicate the need for changes.

The questionnaire was divided into three sections. In the first section, those interviewed were asked to choose from among five international NGOs - Médecins du Monde (Doctors of the World), Red Cross, Caritas, UNICEF and AMI - the one that they knew best (interviewers showed them a set of five cards, each with the name and symbol of each NGO). This first question was intended to measure brand awareness through the assisted top-of-mind technique (KELLER, 1993; LAURENT et al., 1995). The choice of these five NGOs is justified by their similarities in terms of their area of activity, their INCPO classification, tradition, geographical coverage and mission. In studies carried out in other countries which used a similar methodology in the choice of NGOs (e.g., VENABLE et al., 2005; CERVERA; RUIZ; KLEEFELDT, 2008), the criterion of fame was also used. However, as in Portugal there is no known study on this subject, it was not possible to follow this criterion. In the second section of the questionnaire, there were 30 statements that the interviewees were asked to score using a 5-point Likert scale, with 1 corresponding to "completely disagree" and 5 corresponding to "completely agree". This section was designed to measure brand awareness and brand image, 
and the intention to donate. The last section asked about the socio-demographic characteristics of the respondents.

\section{RESULTS}

The average age of the sample was 38.9, with respondents' ages ranging between 18 and 83 . Half of the sample were aged 36 or under and $75 \%$ were aged 48 or under. As far as the distribution by gender is concerned, there was an equal number of men and women. The most frequently occurring marital status was "married/cohabiting", although the second most common status - single - was only slightly less frequent. Together, these two marital statuses accounted for $90.37 \%$ of the sample. The most common level of education consisted of people who had completed the 12th (final) year of schooling (high school diploma) (35.02\%). It should also be noted that $65.6 \%$ of the sample had a level of education equivalent to or higher than the 12th year.

As far as the descriptive analysis of the variables included in the questionnaire is concerned, the results for the assessment of knowledge/fame, using the assisted top-of-mind method and brand typicality, are presented below (Table 1).

Table 1 - Analysis of the Brand Awareness (Top-of-Mind) and Typicality

\begin{tabular}{lcccc}
\hline \multicolumn{1}{c}{ NGO } & $\begin{array}{c}\text { Frequency } \\
\text { (top of mind) }\end{array}$ & Mean & $\mathrm{N}$ & $\begin{array}{c}\text { Standard deviation } \\
\text { (typicality) }\end{array}$ \\
\hline Red Cross & $267(40.83 \%)$ & 4.24 & 267 & 0.589 \\
UNICEF & $187(28.59 \%)$ & 4.27 & 187 & 0.554 \\
AMI & $83(12.69 \%)$ & 4.28 & 83 & 0.554 \\
Caritas & $66(10.09 \%)$ & 4.22 & 66 & 0.505 \\
Médecins du Monde & $51(7.80 \%)$ & 4.15 & 51 & 0.559 \\
\hline \multicolumn{2}{r}{ Total } & $654(100 \%)$ & 4.24 & 654
\end{tabular}

The analysis that was carried out shows that the best-known NGO among the respondents was clearly the Red Cross, with $40.83 \%$ choosing this NGO as the one they were most familiar with. Next came UNICEF, with $28.59 \%$. The least well-known NGO was Médecins du Monde, with only $7.80 \%$ of respondents choosing this as the best known of the five NGOs in the study.

The analysis of typicality showed that AMI obtained the highest score for this factor and that, generally speaking, NGOs are a good example of the humanitarian sector and represent their values well. The variability in the answers was similar for the five NGOs. 
We used linear regression to analyze the influence of Brand Image (usefulness, efficiency, affect and dynamism) on the intention to donate money $\left(\mathrm{H}_{1}\right)$ and time $\left(\mathrm{H}_{2}\right)$, as well as to check whether a greater Familiarity with an NGO contributes to a greater intention to donate money $\left(\mathrm{H}_{3}\right)$ and time $\left(\mathrm{H}_{4}\right)$ to that same organization. Correlation analysis was used to check the existence of a relationship between Typicality and Familiarity $\left(\mathrm{H}_{5}\right)$. But, first the descriptive analysis was performed as well as the calculation of the reliability coefficients of the scales used to measure the variables, as is possible to observe in the Appendix. All constructs present mean values higher than 3.7 (Typicality and Affect present the highest scores). The Cronbach's alphas presented in this study are mostly considered as 'good', especially the Affect and the Efficiency dimensions of the Brand Image.

\section{Model 1: The NGO's brand image and the intention to give financial aid}

In order to understand whether the brand image of the NGO influences the intention to give financial aid, a regression analysis was carried out, together with the study of the coefficients of determination and simple correlation, in order to test the research hypothesis $\mathrm{H}_{1}$. However, in order to check whether a functional relationship can be inferred between the dependent variable, the intention to give financial aid to the NGOs (IFAN), and the independent variables, usefulness (U), efficiency (E), affect (A) and dynamism (D), we first needed to check that the model's premises were valid.

However, the analysis made of the regression coefficient through the Student t-test showed that only the independent variable "usefulness" presented a $p$-value of $<0.05$. A new regression was therefore carried out, not including the independent variable "dynamism", as this had presented the highest $p$-value. However, once again, only the independent variable "usefulness" presented a $p$-value of $<0.05$, so that a new regression was carried out, this time including in the model only the variables "usefulness" and "affect".

Analysis of the coefficient of determination, $\mathrm{R}^{2}$, in which $\mathrm{R}^{2}=0.039$, allows us to state that $3.9 \%$ of the variability of the dependent variable IFAN ("It is quite likely that I shall give financial aid to the organization in the next six months") is explained by the independent variables "usefulness" and "affect", with the remaining variability being explained by factors not included in the model. Analysis of the coefficient of simple correlation $(\mathrm{R})$, in which $\mathrm{R}=0.197$, makes it possible to state there is a positive, but weak, correlation $(\mathrm{R}<0.3)$ between the independent variables and the dependent variable, with these tending to vary in the same direction. 
In order to analyze the model's variance, the $F$-test was used, which has an associated $p$ (Sig.) value of 0.000 . With a $p$-value of $<0.05$, the null hypothesis that the dependent and independent variables are not related is rejected, so that it can be stated that the model is highly significant. The regression coefficients $\beta_{\mathrm{i}}$ were analysed through the Student t-test, which presented the following values: usefulness $(\beta=0.215 ; p=0.015)$, affect $(\beta=0.229$; $p=0.011$ ). Since the $p$-value is less than 0.05 , it may be concluded that the independent variables significantly affect the dependent variable, and that the more favorable the brand image related with the dimensions of usefulness and affect is, the greater is the intention to give financial aid to the NGO. Table 2 summarizes the regression analysis used to test Model 1.

Table 2 - Regression Analysis - Model 1

\begin{tabular}{|c|c|c|c|c|c|}
\hline Model & $\mathrm{R}$ & $\mathbf{R}^{2}$ & $\mathbf{R}^{2}$ adj & \multicolumn{2}{|c|}{$\hat{\sigma}$} \\
\hline \multirow[t]{3}{*}{1} & $0.197^{\mathrm{a}}$ & 0.039 & 0.036 & \multicolumn{2}{|c|}{1.0994} \\
\hline & \multicolumn{5}{|c|}{ Analysis of Variance } \\
\hline & SQ & df & QM & $\mathrm{F}$ & Sig. \\
\hline Regression & 31.936 & 2 & 15.968 & 13.210 & $0.000^{\mathrm{a}}$ \\
\hline Error & 786.903 & 651 & 1.209 & - & - \\
\hline \multirow[t]{3}{*}{ Total } & 818.839 & 653 & - & - & - \\
\hline & \multicolumn{5}{|c|}{ Coefficients } \\
\hline & Coeff. & $\sigma$ & $t$ & Sig. & VIF \\
\hline Constant & 0.746 & 0.364 & 2.050 & 0.041 & - \\
\hline Utility & 0.215 & 0.088 & 2.442 & 0.015 & 1.386 \\
\hline Affect & 0.229 & 0.090 & 2.553 & 0.011 & 1.386 \\
\hline
\end{tabular}

a. Predictors: (Constant), Utility, Affect, $\alpha=0.05$

Thus, hypothesis $\mathrm{H}_{1}$ - The NGO's brand image influences the intention to give financial aid - is partly supported, since only two (usefulness and affect) of the four dimensions of the brand image proved to be relevant to explain the intention to donate money to the NGO.

The results obtained do not converge totally with those of other similar studies, although they do display several common features. The results obtained by Venable et al. (2005) and Michel and Rieunier (2012) clearly showed that brand personality and the four dimensions of brand image were strongly correlated with the intention to give financial aid. According to Venable et al. (2005), brand personality explains between $30 \%$ and $40 \%$ of the 
intention to give financial aid to an NGO, while for Michel and Rieunier (2012) $31 \%$ of this intention is explained by the four dimensions of brand image. The difference between the results obtained by these authors and those obtained in this research lies first in the correlation that was obtained (3.6\%). Second, this study showed that only the dimensions of usefulness and affect were relevant to explain the intention to donate money to the NGO. In the study carried out by the last authors, efficiency $(\beta=0.300)$ was identified as the dimension that most contributes to the intention to give financial aid. In contrast to this, however, in this study that dimension was not shown to be a significant predictor, and was even excluded from the model. Affect $(\beta=0.229)$ was the dimension that best explained the intention to donate money.

\section{Model 2: The NGO's brand image and the intention to donate time (volunteering)}

To check whether the NGO's brand image influences the intention to donate time to the organization, a regression analysis was carried out to test the research hypothesis $\mathrm{H}_{2}$. Once again, in order to check if it was possible to infer a functional relationship between the dependent variable, the intention to donate time to the NGO (IDTN), and the independent variables, usefulness (U), efficiency (E), affect (A) and dynamism (D), it was first of all necessary to ensure that the model's premises were valid.

Analysis of the regression coefficient through the Student t-test showed that only the independent variable "efficiency" presented a $p$-value of $<0.05$, which, after successive attempts to calculate the regression (excluding the non-significant variables), was included in the model.

Analysis of the coefficient of determination, $\mathrm{R}^{2}$, in which $\mathrm{R}^{2}=0.017$, allows us to state that $1.7 \%$ of the variability of the dependent variable IDTN ("It is quite likely that I shall do some volunteering at the organization in the next six months") is explained by the independent variable "efficiency", with the remaining variability being explained by factors not included in the model. Analysis of the coefficient of simple correlation $(\mathrm{R})$, in which $\mathrm{R}=0.132$, makes it possible to state there is a positive, but weak, correlation $(\mathrm{R}<0.3)$ between the independent variable and the dependent variable.

The model is highly significant since $F$ has an associated $p$ (Sig.) value of 0.000 . As far as the regression coefficients were concerned, the Student t-test presented the following value: efficiency $(\beta=0.256 ; p=0.001)$. Since the $p$-value is less than 0.05 , it can be concluded that the independent variable significantly affects the dependent variable and that the more the brand 
image is related with the dimension "efficiency", the greater is the intention to donate time to the NGO. Table 3 summarizes the regression analysis used to test Model 2.

Table 3 - Regression Analysis - Model 2

\begin{tabular}{|c|c|c|c|c|c|}
\hline Model & $\mathrm{R}$ & $\mathbf{R}^{2}$ & $\mathbf{R}^{2 \text { adj }}$ & \multicolumn{2}{|c|}{$\hat{\sigma}$} \\
\hline \multirow[t]{3}{*}{2} & $0.132^{\mathrm{a}}$ & 0.017 & 0.016 & \multicolumn{2}{|c|}{1.0774} \\
\hline & \multicolumn{5}{|c|}{ Analysis of Variance } \\
\hline & SQ & df & QM & $\mathrm{F}$ & Sig. \\
\hline Regression & 13.465 & 1 & 13.465 & 11.601 & $0.000^{\mathrm{a}}$ \\
\hline Error & 756.768 & 652 & 1.161 & - & - \\
\hline \multirow[t]{3}{*}{ Total } & 770.232 & 653 & - & - & - \\
\hline & \multicolumn{5}{|c|}{ Coefficients } \\
\hline & Coeff. & $\sigma$ & $t$ & Sig. & VIF \\
\hline Constant & 1.294 & 0.293 & 4.418 & 0.000 & - \\
\hline Efficiency & 0.256 & 0.075 & 3.406 & 0.001 & 1.000 \\
\hline
\end{tabular}

a. Predictors: (Constant). Efficiency. $\alpha=0.05$

Thus, the research hypothesis $\mathrm{H}_{2}$ - The NGO's brand image influences the intention to donate time (volunteering) - is partly supported, since only one of the four dimensions of brand image (efficiency) was shown to be relevant to explain the intention to donate time to the NGO.

The results obtained are slightly different from those obtained by Michel and Rieunier (2012), which clearly showed that the four dimensions of brand image were correlated with the intention to donate time. In this research, only the dimension "efficiency" was shown to be relevant to explain that intention, presenting a similar beta value to the original study. Another difference to be noted between the results of this study and those of Michel and Rieunier (2012) is the values of $R^{2}$ ( 0.017 and 0.24 respectively).

\section{Model 3: Familiarity with the NGO and the intention to give financial aid}

To corroborate $\mathrm{H}_{3}$, a regression analysis was carried out, together with the study of the coefficients of determination and simple correlation. As was the case with the previous hypotheses, a check was made to see if a functional relationship could be inferred between the dependent variable, the intention to give financial aid to the NGO (IFAN), and the independent variable "familiarity" (FAM). 
The analysis of the coefficient of determination, $\mathrm{R}^{2}$, in which $\mathrm{R}^{2}=0.025$, allows us to state that $2.5 \%$ of the variability of the dependent variable IFAN is explained by the independent variable "familiarity". The coefficient of simple correlation (R), in which $\mathrm{R}=0.159$, makes it possible to state there is a positive, but weak, correlation $(\mathrm{R}<0.3)$ between the variables.

In order to analyze the model's variance, the $F$-test was used, which has an associated $p$ (Sig.) value of 0.000 . As the $p$-value is lower than 0.05 , the model is highly significant. The regression coefficients $\beta_{1}$ were analyzed through the Student t-test, which presented the following value: familiarity $(\beta=0.300 ; p<0.001)$. Since the $p$-value is lower than 0.05 , it can be concluded that the independent variable significantly affects the dependent variable and that the greater the familiarity with the NGO is, the greater is the intention to give financial aid.

From the values obtained for the regression coefficients, it can be said that for each unit variation of the independent variable "familiarity", the estimated variation in the dependent variable IFAN is $30.0 \%$. Table 4 summarizes the regression analysis used to test Model 3.

Table 4 - Regression Analysis - Model 3

\begin{tabular}{|c|c|c|c|c|c|}
\hline Model & $\mathrm{R}$ & $\mathbf{R}^{2}$ & $\mathbf{R}^{2}$ adj & \multicolumn{2}{|c|}{$\hat{\sigma}$} \\
\hline \multirow[t]{3}{*}{3} & $0.159^{\mathrm{a}}$ & 0.025 & 0.024 & \multicolumn{2}{|c|}{1.1064} \\
\hline & \multicolumn{5}{|c|}{ Analysis of Variance } \\
\hline & SQ & df & QM & $\mathrm{F}$ & Sig. \\
\hline Regression & 20.748 & 1 & 20.748 & 16.950 & $0.000^{\mathrm{b}}$ \\
\hline Error & 798.091 & 652 & 1.224 & - & - \\
\hline \multirow[t]{3}{*}{ Total } & 818.839 & 653 & - & - & - \\
\hline & \multicolumn{5}{|c|}{ Coefficients } \\
\hline & Coeff. & $\sigma$ & $t$ & Sig. & VIF \\
\hline Constant & 1.421 & 0.290 & 4.902 & 0.000 & - \\
\hline Familiarity & 0.300 & 0.073 & 4.117 & 0.000 & 1.000 \\
\hline
\end{tabular}

a. Predictors: (Constant), Familiarity, $\alpha=0.05$

Thus, the research hypothesis $\mathrm{H}_{3}$ - The greater the familiarity with the NGO is, the greater will be the intention to give financial aid - is supported. The result obtained points to the acceptance of the hypothesis that was formulated, since familiarity with the NGO is related with the intention to give financial aid. 
The results that were obtained seem to run counter to those presented by Faircloth (2005). In his study, the more familiar respondents were with the NGO, the less willing they were to help it $(\beta=-0.177 ; p<0.05)$. He described this evidence as counterintuitive.

\section{Model 4: Familiarity with the NGO, and the intention to donate time (volunteering)}

To corroborate the research hypothesis $\mathrm{H}_{4}$, a regression analysis was carried out, together with a study of the coefficients of determination and simple correlation. In order to check if a functional relationship could be inferred between the dependent variable, the intention to donate time to the NGO (IDTN), and the independent variable, familiarity (FAM), it was necessary to ensure that the premises of the model were valid.

Analysis of the coefficient of determination, $\mathrm{R}^{2}$, in which $\mathrm{R}^{2}=0.022$, allows us to state that $2.2 \%$ of the variability of the dependent variable IDTN is explained by the independent variable "familiarity", while the remaining variability is explained by factors that are not included in the model. The coefficient of simple correlation $(\mathrm{R}=0.149)$ shows there is a positive, but weak, correlation $(\mathrm{R}<0.3)$ between the independent variable and the dependent variable, with these both tending to vary in the same direction.

In order to analyze the model's variance, the $F$-test was used, which has an associated $p$ (Sig.) value of 0.000 , so that the model is considered to be highly significant. The regression coefficients $\beta_{\mathrm{i}}$ were analyzed using the Student t-test, which presented the following values: familiarity $(\beta=0.272 ; p<0.001)$. Since the $p$-value is lower than 0.05 , it can be concluded that the independent variable significantly affects the dependent variable and that the greater is the familiarity, the greater will be the intention to donate time to the NGO.

From the values obtained for the regression coefficients, it can be stated that for each unit variation of the independent variable "familiarity", the estimated variation in the dependent variable IDTN is $27.2 \%$. Table 5 summarizes the regression analysis used to test Model 4. 
Table 5 - Regression Analysis - Model 4

\begin{tabular}{|c|c|c|c|c|c|}
\hline Model & $\mathrm{R}$ & $\mathbf{R}^{2}$ & $\mathbf{R}^{2 \text { adj }}$ & \multicolumn{2}{|c|}{$\hat{\sigma}$} \\
\hline \multirow[t]{3}{*}{4} & $0.149^{\mathrm{a}}$ & 0.022 & 0.021 & \multicolumn{2}{|c|}{1.0748} \\
\hline & \multicolumn{5}{|c|}{ Analysis of Variance } \\
\hline & SQ & df & QM & $\mathrm{F}$ & Sig. \\
\hline Regression & 17.082 & 1 & 17.082 & 14.788 & $0.000^{\mathrm{a}}$ \\
\hline Error & 753.150 & 652 & 1.155 & - & - \\
\hline \multirow[t]{3}{*}{ Total } & 770.232 & 653 & - & - & - \\
\hline & \multicolumn{5}{|c|}{ Coefficients } \\
\hline & Coeff. & $\sigma$ & $t$ & Sig. & VIF \\
\hline Constant & 1.211 & 0.282 & 4.299 & 0.000 & - \\
\hline Familiarity & 0.272 & 0.071 & 3.845 & 0.000 & 1.000 \\
\hline
\end{tabular}

a. Predictors: (Constant), Familiarity, $\alpha=0.05$

Thus, the research hypothesis that was formulated $\mathrm{H}_{4}-$ The greater the familiarity with the NGO is, the greater will be the intention to donate time (volunteering) - is supported. The result obtained points to the acceptance of the hypothesis, since familiarity with the NGO is related with the intention to donate time to the NGO. As was already mentioned in the previous model, the results obtained run counter to those obtained by Faircloth (2005).

\section{Typicality noted in relation to the $N G O$ and familiarity}

The research hypothesis $\mathrm{H}_{5}$ was checked by analyzing the correlation between the variables "typicality" and "familiarity". The results obtained showed there is a relationship between typicality and familiarity, with the Pearson coefficient amounting to 0.405 . As $0.3<$ $\rho<0.7$, it is considered that there is a positive, but moderate, correlation between the variables "typicality" and "familiarity" (see Table 6).

Table 6 - Pearson Correlation Between Familiarity and Typically

\begin{tabular}{lccc}
\hline & Pearson Correlation & Sig. (2-tailed) & N \\
\hline Familiarity & 0.405 & 0.000 & 654 \\
Typicality & & &
\end{tabular}

Thus, the research hypothesis $\mathrm{H}_{5}-$ The typicality noted in relation to the NGO is linked to brand awareness - is supported. There is a moderate correlation between the variables and this is significant $(p<0.001)$ at a $5 \%$ level. We are unaware of other studies that have tested this relationship, so that it is not possible to make any direct comparison with these results. 


\section{CONCLUSIONS}

This study replicated a scale, recently developed and used by Michel and Rieunier (2012), for nonprofit brand image using a sample of Portuguese respondents regarding five NGOs, emphasizing the emerging role of brand image in donor intention. The familiarity with the organization was also evaluated regarding its relation with the intention to give time or money.

Through an analysis of brand awareness using the assisted top-of-mind method, it was found that the NGO that was best known by respondents was the Red Cross. As far as their attitudes towards donation and the intention to donate resources is concerned, we found that more than half of the sample were not in the habit of giving financial aid to charitable organizations and that only $21.71 \%$ of respondents expressed the intention to make donations to the chosen NGO within the next six months. Stress should be placed on the low percentage of the number of individuals interviewed who claimed to have already engaged in volunteering activities (28.59\%). As far as their intention to engage in volunteering at the chosen NGO in the next six months is concerned, only $9.48 \%$ of those interviewed expressed their agreement with this statement.

The testing of the research hypotheses made it possible to conclude that some of the dimensions of brand image (usefulness and affect) contribute to the intention to give financial aid to NGOs. Usefulness and affect explain 3.9\% of that intention. As far as the intention to donate time is concerned, only the dimension of efficiency is significant in the variability of that intention. Efficiency explains $1.7 \%$ of the intention to engage in volunteering. Earlier studies presented quite different results in regard to this subject. On the one hand, the work of Michel and Rieunier (2012) shows that the intention to donate time and money is strongly explained by the four dimensions of the brand image. On the other hand, the study by Sargeant, Ford and Hudson (2008) points in the opposite direction, concluding that this intention cannot be explained by some of these factors.

Since efficiency plays an important role in the intention to engage in volunteering, it is important for NGOs to succeed in transmitting this image of efficiency. It is quite likely that organizations that have a more technical function (e.g., Médecins du Monde) find it easier to work on this aspect. Nonetheless, other dimensions of the brand image, such as usefulness, dynamism and affect, must not be neglected. As far as this last aspect is concerned, the management of the brand must be directed towards the creation of emotional ties with the public. 
Familiarity with the NGO contributes positively to the variability both of the intention to donate money and of the intention to donate time. It explains $2.5 \%$ of the intention to donate money and $2.2 \%$ of the intention to donate time. The results obtained here run counter to those presented by Faircloth (2005). In his study, the more familiar that respondents were with the NGO, the less willing they were to help it $(\beta=-0.177 ; p<0.05)$. He described this evidence as being counterintuitive.

It should be noted that in the four models proposed to predict the intention to donate, the variance explained both by the brand image and by familiarity with the NGO accounts for only a small percentage of individuals' behavior. This fact suggests it is necessary to discover what other factors contribute to the intention to donate either time or money to NGOs. For instance, the emotional dimensions of nonprofit brands probably will be more likely to exert a stronger influence than the functional dimensions on intentions to donate (especially when trying to attract more volunteers), as argued by Michel and Rieunier (2012). Nevertheless, some NGOs tend to devote less effort to the emotional side of their relationship with donors, instead focusing on the interaction and dialog with stakeholders, on the coherence of the brand (the same image to internal and external publics) and on the affect, as recommended by Ewing and Napoli (2005). These authors agree that charities have to understand how to create emotions linked to their brand.

The relationship between brand typicality and familiarity was checked. Except for the study by Michel and Rieunier (2012), which validated the relationship between typicality and the intention to donate, no other studies were found that made it possible to compare the results obtained.

In terms of managerial implications, we think it is possible for nonprofit organizations to use the brand image scale presented here in their examination of donors' attitudes, and volunteers' behaviors. This exercise can be useful to situate the organization's image in relation to its competitors and to conceive the communication campaigns more effectively, in order to better target potential donors and volunteers.

The main limitation of this study is due to the fact that it covered only a limited number of NGOs, which may not be completely representative of the whole third sector. This limitation therefore prevents extrapolation of the results obtained to other NGOs. Another limitation of the research is due to the fact that the study used possible donors/volunteers as its sample instead of using actual donors/volunteers. In this way, what was analyzed would have been the influence of the brand image on the real behavior of those making donations or 
engaging in volunteering instead of the intention to donate shown by possible donors/volunteers. In this case, our results demonstrate that respondents were not very predisposed towards making donations, so the final results were certainly affected by this particular feature of the sample.

Studies whose samples included only people who are already engaged in volunteering or already making financial donations would make it possible to have a different perspective of the attributes of brand personality and brand image that are most valued by those who effectively contribute to NGOs. In future we intend to perform a study that could differentiate potential and actual donors/volunteers, in order to better distinguish their attitudes and behaviors. Additionally, a structural model will be tested to observe and measure how the variables interact.

\section{Acknowledgements}

NECE - R\&D Centre funded by the Multiannual Funding Programme of R\&D Centres of FCT (Portuguese Foundation for Science and Technology).

\section{REFERENCES}

AAKER, D. Managing brand equity: capitalizing on the value of a brand name. New York: The Free Press, 1991.

Building strong brands. New York: The Free Press, 1996.

BAGHI, I.; GABRIELLI, V. Co-branded cause-related marketing campaigns: the importance of linking two strong brands. International Review of Public and Nonprofit Marketing, v. 10, n. 1, p. 13-29, 2013.

BAKER, W. et al. Brand familiarity and advertising: effects on the evoked set and brand preference. Advances in Consumer Research, v. 13, n. 1, p. 637-642, 1986.

BENNETT, R., GABRIEL, H. Image and reputational characteristics of UK charitable organizations: an empirical study. Corporate Reputation Review, v. 6, n. 3, p. 276-289, 2003.

CERVERA, A.; RUIZ, M. E.; KLEEFELDT, B. Aplicabilidad de los conceptos de imagen corporativa y posicionamento a las ONGD. In: INTERNATIONAL CONGRESS ON PUBLIC AND NONPROFIT MARKETING, 7., 2008, Szeged (HUN). Anais... Szeged: ICPNM, 2008.

CHIAGOURIS, L. Non profit brands come of age. Marketing Management, v. 14, n. 5, p. 30-33, 2005.

DAW, J. et al. Breakthrough nonprofit branding: seven principles for powering extraordinary growth. New York: AFP, 2010. p. 19-34. 
EINWILLER, S. The significance of reputation and brand for creating trust in the different stages of a relationship between an online vendor and its customers. In: Research Symposium on on Emerging Electronic Markets, 8., 2001, Maastricht (HOL). Anais... Maastricht: RWTH, 2001. p. 1-17.

EWING, M. T.; NAPOLI, J. Developing and validating a multidimensional nonprofit brand orientation scale. Journal of Business Research, v. 58, n. 6, p. 841-53, 2005.

FAIRCLOTH, J. B. Factors influencing nonfrofit resource provider support decisions: applying the brand equity concept to nonprofits. Journal of Marketing Theory and Practice, v. 13, n. 3, p. 1-15, 2005.

FRUMKIN, P.; KIM, M. T. Strategic positioning and the financing of nonprofit organizations: is efficiency rewarded in the contributions marketplace? Public Administration Review, v. 61, n. 3, p. 266-289, 2001.

GUY, B. S.; PATTON, W. E. The marketing of altruistic causes: understanding why people help. Journal of Consumer Marketing, v. 6, n. 1, p. 19-30, 1989.

HOEFFLER, S.; KELLER, K. L. Building brand equity through corporate societal marketing. Journal of Public Policy and Marketing, v. 21, n. 1, p. 78-89, 2002.

JUDD, N. On branding: building and maintaining your organization's brand in an AMC. Association Management, v. 56, n. 7, p. 17-1, 2004.

KELLER, K. L. Conceptualizing, measuring, and managing customer-based brand equity. Journal of Marketing, v. 57, n. 1, p. 1-22, 1993.

LAURENT, G.; KAPFERER, J. N.; ROUSSEL, F. The underlying structure of brand awareness scores. Market Science, v. 14, n. 3, p. G170-G179, 1995.

LIU, W.; AAKER, J. The happiness of giving: the time-ask effect. Journal of Consumer Research, v. 35, n. 3, p. 543-57, 2008.

MACKENZIE, S.; LUTZ, R.; BELCH, G. The role of attitude toward the ad as a mediator of advertising effectiveness: a test of competing explanations. Journal of Marketing Research, v. 23, n.2, p. 130-143, 1986.

MEWS, M.; BOENIGK, S. Does organizational reputation influence the willingness to donate blood? International Review of Public and Nonprofit Marketing, v. 10(1):49-64, 2013.

MICHEL, G.; RIEUNIER, S. Nonprofit brand image and typicality influences on charitable giving. Journal of Business Research, v. 65, n. 5, p. 701-707, 2012.

MORT, G. S.; WEERAWARDENA, J.; WILLIAMSON, B. Branding in the non-profit context: the case of Surf Life Saving Australia. Australasian Marketing Journal, v. 15, n. 2, p. 108-119, 2007.

NADDAFF, A. Branding by design. Communication World, v. 21, n. 5, p. 18-21, 2004.

REES, P. L. Marketing in the UK and US not-for-profit sector: the import mirror view. The Services Industry Journal, v. 18, n. 1, p. 113-131, 1998. 
SALAMON, L. M. et al. Portugal's nonprofit sector in comparative context. The Johns Hopkins University Institute for Policy Studies, Baltimore, 2012. Disponível em:

$<$ http://ccss.jhu.edu/wp-content/uploads/downloads/2012/04/Portugal_ComparativeReport_FINAL_4.2012.pdf>. Acesso em: $10 \mathrm{dez} .2012$.

SAMU, S.; WYMER, W. The effect of fit and dominance in cause marketing communications. Journal of Business Reserach, v. 62, n. 4, p. 432-40, 2009.

SARGEANT, A.; FORD, J.; HUDSON, J. Charity brand personality: the relationship with giving behavior. Nonprofit and Voluntary Sector Quarterly, v. 37, n. 3, p. 468-491, 2008.

SARGEANT, A.; HUDSON, J.; WEST, D. C. Conceptualizing brand values in the charity sector: the relationship between sector, cause and organization. Services Industry Journal, v. 28, n. 5, p. 615-632, 2008.

SMILLIE, I. The alms bazaar: altruism under fire: non-profit organizations and international development. Ottawa: IDRC, 1995.

STINNETT, R. C.; HARDY, E. E.; WATERS, R. D. V. Who are we? The impacts of anthropomorphism and the humanization of nonprofits on brand personality. International Review of Public and Nonprofit Marketing, v. 10, n. 1, p. 31-48, 2013.

VENABLE, B. T. et al. The role of brand personality in charitable giving: an assessment and validation. Academy of Marketing Science Journal, v. 33, n. 3, p. 295-312, 2005.

WEBSTER, K. K. Branding the non-profit. Social Service Journal, v. 5, p. 5-7, 2002.

WILSON, A.; PIMM, G. The tyranny of the volunteer: the care and feeding of voluntary workforces. Management Decision, v. 34, n. 4, p. 24-40, 1996.

WYMER, W. Deconstructing the brand nomological network. International Review of Public and Nonprofit Marketing, v. 10, n. 1, p. 1-12, 2013.

\section{APPENDIX}

Typicality [M(4,244), Cronbach's alpha(0,814)]

1. Organization $\mathrm{X}$ is representative of the idea I have of the humanitarian sector

2. Organization $\mathrm{X}$ is a good example of the humanitarian sector

Familiarity [M(3.934), Cronbach's alpha(0.707)]

3. Organization $\mathrm{X}$ is familiar to me

4. I'm aware of organization $\mathrm{X}$

5. I have knowledge of organization $X$

BRAND IMAGE

Usefulness (U) [M(4.261), Cronbach's alpha(0.764)] 
6. The work performed by organization $\mathrm{X}$ is indispensable

7. The work performed by organization $\mathrm{X}$ is useful

8. Organization X takes care of society's needs and interests

Efficiency (E) [M(3.864), Cronbach's alpha(0.844)]

9. The activities of organization $X$ are performed efficiently

10. Organization $\mathrm{X}$ is a serious organization

11. I consider organization $\mathrm{X}$ to be well managed

12. Organization $X$ provides excellent services to beneficiaries

13. The resources of the organization $\mathrm{X}$ are wisely used

Affect (A) [M(4.097), Cronbach's alpha(0.855)]

14. Organization $\mathrm{X}$ is friendly

15. Organization $X$ is generous

16. Organization $\mathrm{X}$ is warm

17. Organization $X$ is engaging

Dynamism (D) [M(3.716), Cronbach's alpha(0.772)]

18. Organization $\mathrm{X}$ is a modern organization

19. Organization $X$ is an innovative organization 